УДК 323.1

А. А. Слинько,

Е. Б. Кулаков,

Ю. И. Лаптева,

Т. В. Полянчук

\title{
РЕАЛИЗАЦИЯ ГОСУДАРСТВЕННОЙ НАЦИОНАЛЬНОЙ ПОЛИТИКИ В РОССИИ: РЕГИОНАЛЬНЫЙ АСПЕКТ
}

\begin{abstract}
Аннотация: статья поднимает вопросье ббормирования в Российской Федерации долгосрочной национальной политики, на основе которой осуществляется координация деятельности органов государственной власти и местного самоуправления, их взаилодействие с институтами гражданского общества. Цель статьи: рассмотреть исторический аспект формирования национальных отношений в Российской Федерации и современный этап их реализации, заострив внимание на деятельности национальных общественных организаций на региональном уровне.

В статье отлечено, что в Воронежской области сложилась достаточно стабильная ситуация в плане межнациональных или межэтнических отношений, но существует целый ряд этиоконфблктогенных фбакторов, которье логут эту ситуацию изменить. Суцествует потребность в разработке региональной норлативно-правовой базы, устанавливающей характер и закрепляющей основные направления межнационального взаимодействия в регионе.

Ключевые слов а: государственная национальная политика, национальнье отношения, диаспора, национальнье общественнье организации, Национальная палата.
\end{abstract}

UDK 323.1

A. A. Slinko,

E. B. Kulakov,

Y. I. Lapteva,

T. V. Polyanchuk

\section{IMPLEMENTATION OF THE RUSSIAN FEDERATION'S STATE NATIONALITIES POLICY: THE REGIONAL PERSPECTIVE}

Abstract: the article raises the issues of the formation of a long-term national policy in Russia, which determines the coordination of the activities of the state authorities and local government and their interaction with civil society institutions. The purpose of the article is to examine the historical aspects of the developing national relations in the Russian Federation and the current stage of their implementation, with particular reference to the activities of national public organizations at the regional level.

The article specifies that there is a reasonably stable situation with regard to international or interethnic relations in the Voronezh region, but there are a number of ethnical conflict factors that can change this situation. There is a need to develop legal and regulatory frameworks that establishes the nature and sets out the main directions of interethnic interaction in the region.

Key words: state national policy, national relations, diaspora, national public organizations, the National Chamber.

\section{Введение}

Нащиональная политика Российской Федерации опирается на обшие принципы управления нащиональными прощессами и отношениями, она включает демократические правовые механизмы регулирования межнациональных отношений, особенно кондликтных отношений, также к ее составляющим следует отнести меры, направленные на выявление и превентивное урегулирование межэтнических конфлликтов, меры, направленные на обеспечение свободы развития национальной культуры и сохранения национальной самобытности. Субъек- 
том национальной политики, прежде всего, является государство - входяшие в систему органов государственного и муниципального управления институты центральной, региональной и муниципальной власти. Другие, негосударственные институты политической системы, такие как политические партии, СМИ, гражданское обшество в современном демократическом государстве также активно участвуют в формировании национальной политики.

Стратегия государственной национальной политики в РФ на период до 2025 года служит основой для координащии деятельности органов государственной власти и местного самоуправления, их взаимодействия с институтами гражданского обшества при реализации государственной национальной политики Российской Федерапии и направлена на активизаџию всестороннего сотрудничества народов Российской Федерации, развития их национальных языков и культур [1].

Исторический аспект формирования национальных отношений в Российской Федерации

Исторический аспект формирования национальных отношений в нашей стране играет огромную роль. Исследователи национальных отношений, разделяюшие представления о том, что современные нации являются ровесниками модернизаџионных процессов, относят к конщу XVIII века зарождение русского национализма [2]. Они отмечают, что с этого времени отношение к населению вновь присоединяемых территорий изменяется. Они подвергаются русской колонизации, что закладывает основы для грядуших межэтнических конфликтов и развития сепаратизма.

Российская модернизация, начатая радикальными петровскими реформами, рост национального самосознания, подогреваемый соперничеством с европейскими державами и противостоянием наполеоновскому напествию стали движушими силами развития русского национализма. Развитие национального литературного языка, национальной модели управления породили распространение различных вариантов напиональной идеи в обшественном сознании. Их диапазон был достаточно шширок - от офрицильной доктрины «Џравославие, само- державие, народность» до славянофильства и панславистских геополитических проектов Н. Данилевского и К. Леонтьева. Самоопределение по отношению к Западу стало стержнем процессов осмысления исторической роли России, что характерно для стран «вторичной» модернизации. При этом преобладаюшей моделью нащионализма был налэтнический проект. Но число сторонников гражданского понимания нащии, сопряженного с политическим полноправием и приоритетом индивидуальных, а не коллективных прав, было ограниченно умеренными либералами, типичными представителями которых были члены и сторонники партии конституционных демократов, возникшей после револющии 1905 г. В своем понимании нащии, как объединяюшей представителей различных этнических групп обшности, они были близки запалным либералам того периода, в представлении которых подлерживаемый государством гражданский национализм неизбежно приведет к ассимиляции меньшинств и стиранию различий [3].

В Советском Союзе, несмотря на идеологию, основанную на принщипах интернапионализма, понятие этнического не было лишено политического смысла. В начале советской истории предоставление автономии политическим единицам на основе этнического самоопределение было избрано в качестве инструмента обеспечения их лояльности новому строю. В дальнейшем нашиональная политика способствовала созданию этнократий, что многие исследователи считают миной замедленного действия, заложенной под такую сконструированную обшность как многонациональный сою3 братских народов СССР [4].

Зарубежный исследователь наџиональных проблем на постсоветском пространстве Р. Брубейкер, придерживающийся инструментального подхода к пониманию национализма, писал, что этнофедерализм как форма территориального управления, дополненный приншипом личной нашиональности сделал национальность одной из основ советского строя [5]. Утвердившееся в период правления Сталина понимание нации как общности, вырастающей из этноса, подразумевало и теоретическую возможность возникновения новых наџий. Ослабление центральной власти и роли коммунистической партии придало этой 
гипотетической возможности реальный политический потенщиал.

Дополнительную сложность создавал такой элемент наследия советской национальной политики как сочетание в рамках одного государства территориального и этнокультурного принципов национальности, при котором некоторые этнические группы имели статус «титульных», возможность формирования этнических политических элит и инструменты институциональной поддержки своих языков, а другие могли лишь пользоваться весьма ограниченной культурной автономией. Двойственность нашиональной политики советского периода отечественной истории предопределила многие сложности, с которым пришлось столкнуться новой постсоветской России.

Деятельность национальных общественных организаций на региональном уровне

Задача достижения национального единства и формирования гражданского самосознания россиян остается актуальной и поэтому продолжает оставаться в политической повестке дня. А управление подобными процессами представляет собой сложную задачу, поскольку «современная идентичность населения России представляет собой сложный конгломерат новой российской, ностальгической советской, социальной, региональной, локальной, этнокультурной, религиозной идентичностей. Естественно, все политические, социально-культурные, экономические трансформации общества находят отражение в государственно-гражданской идентичности» [6]. Гражданская интеграџия полиэтнического общества, которое переживает глубокую социальную трансформацию - исключительно сложная задача, требующая постоянного внимания.

Основной задачей национальных общественных организаций является консолидация соотечественников на основании их культурной общности. Естественно, что центральное направление деятельности подобных организаций - это сохранение национальных традищий, культуры, в том числе национального языка и традиционных семейных пенностей.

При губернаторе Воронежской области была создана Национальная палата в це- лях повышения эффективности реализапии государственной национальной политики на территории Воронежской области, укрепления межнационального согласия и взаимопонимания, сохранения и развития национальной и культурной самобытности народов, проживаюших на территории Воронежской области [7]. Наџионально-культурные организации, действующие на территории Воронежской области, содействуют реализации прав граждан на национально-культурное самоопределение, помогают представителям национальных меньшинств в сохранении самобытности, развитии своего языка, образования и культуры, а также в трудоустройстве, правовом консультировании и социальной адаптации.

Реализуется план работы национальных диаспор Воронежской области с вновь прибываюшей молодежью и трудовыми мигрантами. В рамках этого плана проводятся встречи лидеров национальных общин с указанным контингентом, активизируется работа диаспор с воронежскими ВУЗами [8]. Работа правительства области и национальных диаспор направлена на обеспечение законности, соблюдение прав человека независимо от национальности и гражданства, способствует укреплению дружбы и взаимопонимания между народами.

Хотя, в целом, можно сказать, что на сегодняпний день в Воронежской области сложилась достаточно стабильная ситуация в плане межнациональных или межэтнических отношений, но существует целый ряд этноконфликтогенных факторов, которые могут эту ситуацию изменить в худшую сторону. В качестве таких факторов можно выделить следуюшие: во-первых, геополитическое положение Воронежской области, которая находится между южными районами и центральными областями России, вовторых - это миграция из южных республик России и из бывших стран СНГ. Нелегальная мигращия является благоприятной средой для разжигания межнациональных конфликтов, проявлений религиозного и молодежного экстремизма.

Национальные диаспоры указывают на целесообразность разработки и утверждения Конщепщии нащиональной политики Воронежской области, модернизаџии региональной нормативно-правовой базы, уста- 
навливаюшей характер и закрепляюшей основные направления межнационального взаимодействия в регионе. Концепция национальной политики на региональном уровне должна отражать опыт взаимодействия органов государственного и муниципального управления и национально-культурных организаџий, «болевые проблемы» и механизмы их решения. На её основе необходимо разработать комплексный план мероприятий по реализации национальной политики, который должен содержать: диагностику не только межнациональных отношений, но и этносоциальных процессов в пелом; связь задач реализапии национальной политики на муниципальном уровне с целями устойчивого развития региона; необходимость решения не только меж-, но и внутринациональных проблем и противоречий; мониторинг не только межнапиональных отнопений, но и сопиального самочувствия представителей разных этнических групп.

\section{Выводы}

Важными ориентирами реализащии национальной политики на региональном уровне являются: сохранение устойчивого единства в ситуации этнокультурного разнообразия; воспитание чувства взаимного уважения к культурам разных народов, с учетом того, что доминантой выступают тралищии коренного, местного населения; понимание того, что невозможно достичь благополучия отдельной этнической группы без общего благополучия, что определяет взаимную зависимость и взаимную ответственность.

Практическая сторона реализаџии мер в сфрере государственной наџиональной политики требует повышения роли общественных институтов, в том числе нащионально-культурных и религиозных организаций. Необходимо обеспечение системного участия институтов гражданского общества в социально ориентированной деятельности, включая вопросы укрепления гражданского и духовного единства российской нации, противодействие экстремизму, воспитание патриотизма, сохранение духовных традиций народов России, интеграџию, адаптацию, соџиализаџию и натурализащию мигрантов различной этнической и религиозной принадлежности и др. [9].

\section{ЛИТЕРАТУРА}

1. Исайкин Д. М. Документы программного характера, определяюшие государственную национальную политику [Текст] / Д. М. Исайкин // Актуальные теоретические и практические вопросы развития юридической науки: обшегосударственный и региональный аспекты : материалы Bceроссийской конференции с международным участием. - Пермь : Западно-Уральский институт экономики и права. - 2014. C. $159-169$.

2. Greenfield Liah. Nationalism. Five roads to modernity. - Camb. (Mass); L.: Hard. University press, $1993-$ XII, 581p.

3. Вдовин А. И. Российская нация. Национально-политические проблемы XX века и общенациональная советская идея : автореф. дисс. доктора исторических наук / А. И. Вдовин. - М., 1995. - 38 c.

4. Понарин Э. Д. Нащиональные проблемы на постсоветской территории / Э. Д. Понарин, . Н. Мухаметшина. СПб. : Европейский университет, 2001. C. 77 .

5. Брубейкер M. Мифы и заблуждения в изучении империи и нащионализма / М. Брубейкер. - М., 2010. - 426 c.

6. Слинько А. A. Проблемы достижения гражданского единства в контексте изменения государственной национальной политики РФ. Новый баланс сил на евразийском пространстве / А. А. Слинько, Е. Б. Кулаков, Т. В. Полянчук // Среднерусский вестник общественных наук. - 2017. - Т. 12. № 2 . - C. $77-82$.

7. О создании Национальной палаты при губернаторе Воронежской области : указ Губернатора Воронежской области от 7 сентября 2010 г. № 300-у

8. Культурно-национальные особенности населения Воронежской области. - Воронеж : Центр духовного возрождения Черноземного края, $2013 .-212 \mathrm{c}$.

9. Слинько A. A. Усиление роли гражданского обшества в процессах становления национального государства / А. А. Слинько // Сучасна політична нація: духовноморальні, культурно-етичні та соціальноекономічні засади розвитку : матеріали XIV науковопрактичної конференції. - K. : ВН3 «Нащіональна академія управління», 2014. - C. $70-72$. 
Российская академия народного хозяйства и государственной службы при Президенте РФ (Воронежский фблиал)

Слинько А. А., доктор политических наук, профбессор, заведуюший кафбедрой политологии и политического управления

E-mail: aleksandr_slinko@mail.ru

Тел.: 8 (473) 247-73-75

Кулаков Е. Б., аспирант

E-mail: kulakov.evgeniy.80@mail.ru

Тел.: 8-910-345-74-55
Лаптева Ю. И., кандидат политических наук, доцент, доцент кафедры политологии и политического управления

E-mail: kafppu@vrn.ranepa.ru

Тел.: 8 (473) 247-73-75

Полянчук Т. В., аспирантка

E-mail: polyanchuk.tatyana@mail.ru

Тел.: 8-910-243-22-27

УДК 331.548

В. А. Сльцляев, Л. В. Коваль

\title{
ПРОФОРИЕНТАЦИОННАЯ РАБОТА В ВУЗАХ КАК ОБЬЕКТ СОЦИАЛЬНО-ЭКОНОМИЧЕСКОЙ ПОЛИТИКИ: СОСТОЯНИЕ И КОНТУРЫ ОПТИМИЗАЦИИ
}

\author{
(Публикация подготовлена при поддержке РГНФ и Правительства Воронеюской \\ области, проект 17-16-36004 a/p)
}

Аннотация: в статье рассмотрены и проанализированы актуальные проблемы состояния и совериенствования профбориентационной работь в совреленньх российских вузах как объекта социально-экономической политики. Приоритетное внимание уделено анализу взаимосвязи социально-экономической политики, сфберь образования и профбориентационной работы. Дана авторская характеристика суиности, специфики, структуры и иелей профбориентационной работы в вузах. Исследованы сложсившиеся ббормы и виды профориентационной работы вузов с абитуриентали и студентами. Определены основные направления оптилизации вузовской профориентационной работы. Обоснована необходимость создания в современной России Федерального и региональньх профбориентационньх иентров, способных обеспечить эбббективное управление системой профбориентационной работь в РФ и ее регионах.

Ключевые слова: профбориентационная работа, социально-эконолическая политика, профессиональное самоопределение, кадровые потребности, профессиограммы, профбориентационные центры, социально-трудовые отношения, рынок труда.

UDK 331.548

V.A. Smyshlyaew,

L. V. Koval

\section{PROFESSIONAL WORK IN HIGHER EDUCATION INSTITUTIONS AS OBJECT OF SOCIO-ECONOMIC POLICY: STATUS AND CONTOURS OF OPTIMIZATION}

(The publication was prepared with the support of RGNF and the Government of Voronezh Oblast, project 17-16-36004a/p)

Sum mary: in the article actual problems of a condition and perfection of professional orientation work in modern Russian high schools as object of social and economic policy are considered and analyzed. Priority attention is paid to the analysis of the interrelationship between social and 